удК 338.484

\title{
АНАЛІЗ ДОХОДІВ НАСЕЛЕННЯ ЯК ЧИННИКА ФОРМУВАННЯ ТУРИСТИЧНИХ ПОТОКІВ
}

\section{ANALYSIS OF POPULATION INCOME AS A FACTOR OF FORMATION OF TOURIST FLOWS}

\author{
Клок Олексій Петрович \\ кандидат економічних наук, викладач, \\ Харківський національний економічний університет імені Семена Кузнеця \\ ORCID: https://orcid.org/0000-0002-9591-9460
}

Klok Oleksii

Simon Kuznets Kharkiv National University of Economics

\begin{abstract}
Стаття присвячена питанням використання різновидів показників доходу населення з метою визначення головних ознак та ємності споживчого ринку туристичних послуг у межах одної країни та у групі країн, об'єднаних на основі попередньо обраного критерію, з метою подальшої деталізації стратегії виходу на цільові ринки. Надається розширена характеристика різновидів середньодушового показника доходу, наводяться приклади використання змістової концепції кожної підгрупи у конкретних підходах, що можуть використовуватися підприємствами галузі туризму. Проведена класифікація країн із рівнем доходів нижче за середній (у відповідності до методики Світового банку) на основі міри розбіжності номінального доходу та доходу за паритетом купівельної спроможності. Надано опис типової структури туристичних потоків (міжнародного та внутрішнього туризму) для кожної підгрупи.
\end{abstract}

Ключові слова: дохід на душу населення, міжнародний туризм, туристичні потоки, споживчий попит, диверсифрікація ринків.

Статья посвящена вопросам использования разновидностей показателей дохода населения с целью определения главных признаков и ёмкости потребительского рынка туристических услуг в пределах одной страны и в группе стран, объединенных на основе предварительно выбранного критерия, с целью дальнейшей детализации стратегии выхода на целевые рынки. Представлена расширенная характеристика разновидностей среднедушевого показателя дохода, приводятся примеры применения содержательной концепции каждой подгруппы в конкретных подходах, которые могут использоваться предприятиями отрасли туризма. Проведена классификация стран с уровнем доходов ниже среднего (в соответствии с методикой Всемирного банка) на основе степени расхождения номинального дохода и дохода по паритету покупательной способности. Предоставлено описание типовой структуры туристических потоков (международного и внутреннего туризма) для каждой подгруппы.

Ключевые слова: доход на душу населения, международный туризм, туристические потоки, потребительский спрос, диверсификация рынков.

The article is devoted to the use of various indicators of income in order to determine the main peculiarities and capacity of the consumer market of tourism services within one country and in a group of countries combined on the basis of pre-selected criteria, to further detail the strategy of entering target markets. The relevance of the study is explained by the fact that despite a thorough analysis of motivating factors for the purchase of tourist services and socio-psychological aspects of consumer behaviour depending on the level of population income, the question of delimitation of functions and content of typical macroeconomic indicators of income is insufficiently studied. The purpose of the article is to improve the methodical approach to the analysis of household income as a factor of formation of consumer demand for tourist goods and services. The main task is to substantiate the method of logical choice of the optimal per capita income indicator at the preliminary stage of planning the strategy of entering foreign markets and expanding the range of services offered within the country where the tourist enterprise has its residence. General scientific logical, analytical and statistical research methods were used. Numerical data for further calculations were obtained from open sources of the World Bank and the World Travel and Tourism Council. An extended description of the varieties of per capita income indicators is given, four types (nominal, real, actual, adjusted by purchasing power parity) are distinguished, from which derivative indicators are formed; examples of the implementation of the semantic concept of each subgroup, created on the basis of antagonistic comparison, in specific approaches that 
can be implemented by tourism enterprises and market regulators, are revealed. The classification of countries with below-average incomes (according to the World Bank methodology) is based on the discrepancy degree between nominal income and income at purchasing power parity. Four subgroups of national economies are identified, each of which has shown different characteristics of the tourist flows structure, which included outbound (import), inbound (export) and domestic (consumption by residents within the country) tourism. The description of the typical structure of tourist flows for each subgroup has confirmed the assumption of the significance of the discrepancy between nominal incomes and actual market prices in the process of forming consumer behaviour.

Keywords: per capita income, international tourism, tourist flows, consumer demand, market diversification.

Постановка проблеми. Рівень фрактичного доходу населення є головним показником ємності національного туристичного ринку та ключовим чинником фрормування попиту на рекреаційні послуги, адже у більшості випадків подорожі є, по-перше, товаром високоеластичного попиту, по-друге, не відносяться до продуктів першочергової необхідності. Загальний позитивний стан національної економіки та відкритість кордонів є суттєвим стимулом для зростання туристичних потоків, навпаки, стагнація розвитку господарюючої системи та обмеження короткострокової міграції призводять до занепаду туристичної галузі. Проте, рівень життя населення продовжує відігравати провідну роль у підтриманні туристичного споживання навіть у періоди криз, і тому необхідно розуміти, які показники доходу та їх варіації $\epsilon$ першочерговими у процесі прийняття управлінських рішень керівництвом туристичної компанії чи державними або інституційними регуляторами.

Аналіз останніх досліджень і публікацій. Існування прямої залежності між рівнем доходу та попитом на туристичні послуги серед дослідників вважається беззаперечним, така тенденція була доведена на практиці у багатьох країнах, тому здебільшого наукові роботи присвячені або методам кількісного вимірювання цієї залежності із поступовим ускладненням математичних моделей та розширенням переліку змінних, або нетиповим проявам в основному на локальних ринках, коли аналізується і описується цікавий досвід якоїсь окремої країни або регіону. Вивчення глобального економічного простору у даному контексті ставить на меті визначення першоджерел та наслідків масових ресурсних та міграційних потоків, тобто крупним гравцям ринку цікаво спрогнозувати, чи здатні спричинити масові явища у тій чи іншій галузі кардинальні зрушення, чи то вони пояснюються просто великими масштабами операцій транснаціональних компаній (ТНК) і ніяк не співвідносяться із усталеними глобальними процесами. У межах пропонованої статті зупинимося на наступних аспектах оці- нювання рівня доходу та чинників, що мають на нього безпосередній вплив.

М. Крайснік [1] досліджує процеси відновлення економіки після глобальних криз. Він зазначає, що загальноприйнятої теорії циклічного розвитку світового господарства недостатньо, адже статистичні дані спростовують відновлення одразу після завершення найглибшої фрази занепаду. Грасрік криз носить скоріше характер W-подібної кривої, а спад має «подвійне дно». Тому майже завжди існує певний часовий лаг на відновлення зайнятості, купівельної спроможності та ділової активності, який суперечить плавній лінії на традиційному грасріку циклічності. Це пояснює у тому числі й відставання у межах півроку-року попиту на туристичні послуги від фрази росту після найнижчої точки спаду. $X$. Гюль [2] на прикладі економіки Туреччини доводить існування сильного зв'язку між форомуванням ВВП, надходженнями від надання туристичних послуг та експорту і доходом домогосподарств. Саме останні, особливо у країнах із низьким рівнем життя населення найбільше потерпають від кризових явищ. У свою чергу, зниження середньодушового доходу залишає виробників споживчих товарів (на що найбільше спрямовані витрати домогосподарств) без прибутку, вони не сплачують власним постачальникам, і якщо не спрямувати додатковий потік на підтримку якоїсь 3 цих нижчих ланок, починає розпадатися уся система. Для країн, в економіці яких в"їзний туризм $є$ основним джерелом наповнення державного бюджету, тривалі кризи $є$ подвійно руйнівними. Ф.Н. Кан та ін. [3] перевіряє гіпотезу, що в той час як економічна невизначеність зменшує виїзний туризм (тобто імпорт туристичних послуг), вона може стимулювати внутрішній туризм парадоксальним чином через ефрект стагнації. Цікаво, що в Україні у один з кризових періодів спостерігалася протилежна ситуація - впав середній дохід населення, а туристичні компанії продовжували звітувати про надприбутки. I теоретична поведінкова економіка, і наріжні постулати економіки вільного ринку встали у 
глухий кут. Насправді виявилося, що з причини слабкого прошарку середнього класу, якого фрактично тоді не існувало, частина населення із надвисокими доходами продовжувала подорожувати за кордон (внутрішня рекреаційна інсрраструктура ще не забезпечувала належного рівня обслуговування), а зубожіле населення взагалі перестало користуватися послугами місцевих туристичних компаній, і внутрішній ринок зазнав ще більшого занепаду. Ю.Б. Феленчак [4], досліджуючи останні передкризові роки в Україні, вказує, що зростання рівня життя населення у ролі системи розподільчих відносин активізує збільшення внутрішніх та зовнішніх туристичних потоків. Тим не менш, незважаючи на відновлення туристичної інфрраструктури у межах країни, зростання експорту майже не було. Взагалі, через низку причин громадяни України віддають перевагу відпочинку за кордоном, тому зростання доходів відразу провокує збільшення обсягів імпорту. В.М. Стамат [5] намагається пояснити поведінку споживачів туристичних послуг, і виділяє 3-поміж важливих критеріїв суму щоденних витрат під час подорожі. Отже, потенційні туристи не тільки оцінюють загальну вартість туру, а й враховують додаткові кошти. Більшості українців вважається дивним заощаджувати під час відпочинку, часто родина увесь рік збирає кошти на одно-двотижневу подорож раз на рік, і психологічно готова усе витратити. Такий підхід дивує багатьох іноземців, які вимірюють вартість та цінність додаткових послуг за іншими критеріями. Автори роботи [6] аналізують потоки грошових переказів працівників 3-за кордону, які виступають суттєвим внеском до сукупного доходу домогосподарств у Мексиці (в Україні також склалася подібна ситуація). Але у Мексиці ці надходження стимулюють розвиток внутрішнього туризму. Отримувачі переказів - це бідні родини, які нарешті отримали кошти на відпочинок, і тому миттєво витрачали їх на недорогі доступні послуги. Оскільки таких точкових вливань виявилося у сумі багато, внутрішня інфрраструктура отримала суттєвий поштовх до розвитку. Внутрішній ринок у цілому характеризується нижчою есрективністю, ніж питомі надходження від міжнародних туристичних потоків, але у прикладі з Мексикою, на нашу думку, спрацював ефект масштабу. Нарешті, відзначимо дослідження [7], метою якого є якраз оцінка рентабельності кількісних туристичних потоків у порівнянні 3 грошовими надходженнями, які вони генерують. Автори пропонують кла- сифрікацію країн на дві великі групи: «ефективні країни», які зуміли збільшити дохід від надання туристичних послуг на противагу від збільшення кількості відвідувачів; та «неесективні країни», чиї доходи від туризму зростають повільніше, ніж потоки відвідувачів.

Виділення невирішених раніше частин загальної проблеми. Незважаючи на ґрунтовний аналіз мотивуючих чинників та соціально-психологічних аспектів споживчої поведінки в залежності від рівня життя у окремому регіоні або країні, недостатньо вивченим $\epsilon$ питання розмежування функцій та змістового складу типових макроекономічних показників доходу населення, виокремлення специорічних модифрікацій даних показників для побудови різних варіантів стратегій.

Формулювання цілей статті (постановка завдання). Метою статті $€$ удосконалення методичного підходу до аналізу доходу населення як чинника формування споживчого попиту на туристичні товари і послуги. Основне завдання полягає у обґрунтуванні способу логічного вибору оптимального показника середньодушового доходу на попередньому етапі планування стратегії виходу на зарубіжні ринки та розширення номенклатури пропонованих послуг у межах країни, резидентом якої є туристичне підприємство.

Виклад основного матеріалу дослідження. У міжнародній практиці прийнято виділяти чотири видозміни показника доходу, сукупного чи на душу населення: 1) номінальний (тобто фрактичною сума грошей, які отримує мешканець країни або домогосподарство); 2) реальний (фрактична сума, перерахована на основі індексу інсрляції, індексу споживчих цін або аналогічного коефіцієнту; 3) номінальний дохід за паритетом купівельної спроможності - коригований (1); 4) реальний дохід за паритетом купівельної спроможності, або коригований (2).

Паритет купівельної спроможності (ПКС) це штучний коефріцієнт, призначений для вирівнювання національних макроекономічних показників з метою проведення міжнародних зіставлень. Рідко, але він може бути використаний для порівняння доходів чи інших даних у межах країни, якщо існують суттєві відмінності між різними адміністративними одиницями, тоді найчастіше він носить назву «регіональний коефріцієнт» і використовується здебільшого у внутрішніх розрахунках, наприклад, під час визначення обсягу бюджетних транссрертів або соціальних виплат. Широкого розповсюдження ПКС набув завдяки прак- 
тиці оцінки національних економік Світовим банком, а у основі перерахунку лежать дані стосовно курсів валют, що надаються Міжнародним валютним фоондом (МВФ), та визначений перелік товарів і послуг, що входять до «міжнародного» універсального споживчого кошика. Також Світовий банк надає деякі вартісні показники у перерахунку на т.зв. «міжнародний долар». Таким чином, циорри, які зберігаються у найпопулярніших міжнародних статистичних базах даних, та аналогічні показники у тій самій валюті, що публікуються національними службами статистики, співпадають дуже рідко. Це трапляється тоді, коли держава у точності використовує таку ж саму методику перерахунку базових коефріцієнтів, або завантажує до вибірки вже готові дані. Але частіше експерти міжнародних установ та організацій оброблять однорідні масиви даних, наданих країнами у відповідності до певного порядку звітування, самостійно, щоб уникнути помилок та виявити тенденції, що різко виділяються 3-поміж інших.

Оцінка сукупного доходу (який потім «розподіляється» між жителями країни) здійснюється двома способами: 1) знаходиться обсяг валового внутрішнього продукту, або ВВП (Gross Domestic Product, GDP) - це сума усіх товарів і послуг з урахуванням експорту, вироблених у межах географрічної території країни (результат діяльності національних та іноземних підприємств, якщо вони фрормально розміщені, відповідно до юридичної адреси, на цій території, і $є$ податковими резидентами); 2) до звітності включається валовий національний продукт, або ВНП (Gross National Product, GNP) - сума усіх товарів і послуг 3 урахуванням експорту, вироблених у межах економічної території країни (результат діяльності усіх національних компаній та їх підрозділів, у тому числі розміщених за кордоном, та інвестиції за кордон, що належать громадянам країни). Звісно, надано дуже спрощене тлумачення географрічної та економічної території, принципова різниця полягає у тому, що у першому випадку оцінюється потенціал місцевої ділової інфрраструктури, наскільки держава дозволяє реалізуватися бізнесу на власній території; у другому - аналізується потенціал національного виробника та ділова активність громадян, де вони працюють продуктивніше - у власній державі чи за кордоном. Можна зустріти і терміни Gross Domestic Income (GDI) та Gross National Income (GNI) - слово «продукт» замінено на «дохід», тут акцентується увага, що якомога точніше був врахований увесь обсяг матеріального та нематеріального виробництва, у тому числі срінансові та валютні операції. Наступне питання, яке потрібно вирішити - яку саме кількість мешканців обрати для визначення ВВП/ВНП на душу населення. Окрім внутрішньої міграції, яка може спричинити похибку у валовому регіональному продукті (що сумарно дає потім ВВП чи ВНП), включно до 2020 року зростала інтенсивність міжнародної міграції у глобальних масштабах. Тож яка цифра повинна стояти у знаменнику чисельність резидентів країни чи її громадян? Крім того, у інноваційних галузях, особливо сфрері IT, значні обсяги операцій відбуваються за схемою аутсорсингу, і громадяни країни, не перетинаючи її меж, створюють додатковий продукт для іноземного суб'єкта господарювання. У країнах із невисоким рівнем життя і роботодавець, і працівники намагаються уникнути сплати податків, тож можна стверджувати, що частина населення не приймає участі у виробництві ані внутрішнього, ані національного валового продукту, проте входить до загальної чисельності населення, що використовується для розрахунку середньодушового доходу.

Фактично, у сучасних умовах найдостовірнішим макроекономічним показником, на якому доцільно будувати стратегії розвитку категорії національного туризму (дана категорія складається 3 двох потоків - споживання резидентами туристичних послуг у географрічних межах країни та імпорт туристичних послуг, тобто виїзд громадян держави за кордон) у межах країни, $є$ фрактична сума доходів, яка залишається у третинному секторі після здійснення усіх господарських операцій та проведення необхідних виплат. Вона показує купівельну спроможність резидентів, відповідно - обсяг продукції, яке населення теоретично в змозі придбати. Джерела фрормування доходів потенційних споживачів $€$ важливою складовою комплексного дослідження економічної діяльності країни, але підприємствам, що пропонують послуги кінцевим споживачам, вони не надто цікаві. Це більше завдання державних регуляторів, які повинні здійснювати моніторинг поточного стану ділового середовища та вчасно реагувати на несприятливі структурні перетворення. Комерційні ж підприємства прагнуть реалізувати вироблений продукт, забезпечити лояльність споживачів та отримати прибуток. Зауважимо, що відомі міжнародні статистичні бази даних, тематичні чи уніфріковані, рідко містять виключний пере- 
лік усіх видів та підвидів тієї чи іншої категорії. Світовий банк, наприклад, надає декілька вимірів ВВП, але ВНП (точніше, ВНД) додає до внеску резидентів лише податки національних підприємств-нерезидентів, та трансфрери первинних доходів - так, цілком у відповідності до затвердженої методики, але цікаво було б оцінити повний обсяг доходу, що генерується за кордоном з використанням національних ресурсів; можна знайти кількісні і вартісні характеристики міжнародних туристичних потоків, але немає жодних оцінок внутрішнього ринку. Інтерактивні інструменти Світової ради подорожей і туризму (World Travel \& Tourism Council, WTTC) надають лише вартісні дані (обсяги доходів та витрат), проте у комплексі - на міжнародному та внутрішньому ринку. Однак, не усі країни світу є членами даної організації, і тому дані кількох десятків національних економік відсутні. Тому порівняльний аналіз макроекономічних показників, тим більше за окремою галуззю, $€$ занадто складним завданням, якщо вимагається урахування абсолютно усіх суб'єктів глобальної економічної системи. На практиці, втім, навіть великі транснаціональні компанії не охоплюють господарськими операціями усі без виключення регіони світу. Але вивчення потенціалу поки неактивних на світовому ринку туристичних послуг країн $є$ основою для побудови конкурентоспроможної стратегії у майбутньому періоді; також часто постає завдання вивчення ресурсів, якими володіють конкуренти чи потенційні партнери, для прогнозування стабільності зовнішнього контрагента, особливо у відділеному геограсрічному регіоні, необхідно розуміти стан не одної конкретної країни, а групи держав, пов'язаних геополітично. Досі існують країни, які офріційно не звітують про доходи громадян - це, як правило, держави, на території яких тривають збройні конфрлікти і зрозуміло, що вони не розглядаються як привабливі туристичні ринки, та держави - міжнародні фрінансові центри, для яких дотримання комерційної таємниці та нерозкриття особи інвестора $€$ запорукою позитивної репутації та взагалі існування у якості фрінансового анклаву. 3 іншої сторони, $є$ безліч комбінацій видів показників, які можна використовувати для вирішення практичних завдань, без урахування повного складу параметрів. Більше того, використання не тотожних даних інколи надає кращі результати, аніж порівняння аналогічного ряду чи обмеження одною вибіркою.

Уявімо, що туристичний оператор працює над стратегією географрічної диверси- фрікації та на черговому етапі аналізу проводить класифрікацію країн за рівнем доходу населення - потрібно знайти країни із максимально платоспроможним попитом із вибірки, ссрормованої на попередньому етапі (наприклад, країни було згруповано за типом рекреаційних ресурсів чи іншими критеріями). $€$ декілька варіантів категорії середньодушового доходу (як-от перераховані вище). Чи будуть суттєво відрізнятися рекомендації, отримані у результаті аналізу номінального або реального ВВП, чи ВНП та ВВП? Перш ніж обирати той чи інший показник, необхідно логічно обґрунтувати його сутність та зрозуміти, наскільки ідея даного показника відповідає бажаному результату. Приклад використання антагоністичного підходу представлено у табл. 1.

Виходячи 3 характеристик, наведених у таблиці, можна припустити, що країни із близькими коригуючими коефріцієнтами ПКС (пара показників другої групи) повинні мати приблизно однакову структуру туристичних потоків. Тобто, країни із відносно низькою вартістю життя повинні більше приваблювати іноземних відвідувачів та розвивати внутрішній туризм, а у країнах з високими внутрішніми цінами, що здаються завеликими навіть для резидентів, переважатимуть виїзні туристичні потоки. Доцільно порівнювати країни із одної групи за рівнем абсолютного середньодушового доходу, тому оберемо для аналізу країни із доходом нижчим за середній (усього група включає 50 національних економік, у тому числі й Україну). У 2020 р. Світовий банк змінив підхід щодо економічної класифрікації країн. Як і раніше, виділяються чотири групи (низький дохід, нижчий за середній, вищий за середній, високий), але у основу групування покладено ВНД на душу населення у номінальних цінах (курс валют встановлюється за допомогою так званого атласного методу, що усереднює вплив несподіваних валютних коливань) і відповідно змінені порогові значення у абсолютному вираженні. Так, у країнах $з$ низьким рівнем економічного розвитку середньодушовий дохід не перевищував 1036 доларів США, 3 нижчим за середній рівень - становив від 1036 до 4045 доларів, 3 рівнем вищим за середній - від 4046 до 12535 , а у країнах 3 високим рівнем розвитку дохід на одного мешканця перевищував 12535 доларів США. У 2019 р. ВНД України у поточних цінах складав 3370 доларів США (група країн із доходом нижче за середній, 131-ше місце у рейтингу), а ВНД за ПКС ста- 
Різні виміри показника середньодушового доходу

\begin{tabular}{|c|c|c|c|}
\hline № & $\begin{array}{l}\text { Антагоністична } \\
\text { пара показників }\end{array}$ & Сутність & Варіант використання \\
\hline \multirow{2}{*}{ I } & $\begin{array}{l}\text { Номінальний } \\
\text { дохід }\end{array}$ & $\begin{array}{l}\text { Фактична сума доходу, що } \\
\text { використовується для поточної } \\
\text { звітності, нарахування } \\
\text { обов'язкових платежів та } \\
\text { розмежування соціальних } \\
\text { виплат }\end{array}$ & $\begin{array}{l}\text { Туристичні формальності (докумен- } \\
\text { тарне підтвердження граничних норм } \\
\text { доходу для дозволу на перетин кор- } \\
\text { дону у візових країнах; встановлення } \\
\text { коефіцієнтів у актуарних розрахунках } \\
\text { для цілей туристичного страхування; } \\
\text { забезпечення пільг за програмами } \\
\text { соціального туризму) }\end{array}$ \\
\hline & Реальний дохід & $\begin{array}{l}\text { Сума доходу, скоригована } \\
\text { на індекс інфрляції (індекс } \\
\text { споживчих цін та ін.). } \\
\text { Перерахунок може } \\
\text { відбуватися на базі одного } \\
\text { року чи ланцюгово, за даними } \\
\text { попереднього періоду }\end{array}$ & $\begin{array}{l}\text { Довіра споживачів до економічної } \\
\text { політики держави, очікування у } \\
\text { майбутньому кращого чи гіршого } \\
\text { періоду. Тип споживчої поведінки - } \\
\text { відкладання, інвестування чи } \\
\text { поточне витрачання. Прогнозування } \\
\text { сприятливих періодів для розрахунку } \\
\text { із постачальниками }\end{array}$ \\
\hline \multirow[b]{2}{*}{ II } & Фактичний дохід & $\begin{array}{l}\text { Кошти, які потенційний } \\
\text { споживач отримує у вигляді } \\
\text { надходжень. Фіксована сума } \\
\text { (готівкою чи у безготівковому } \\
\text { вигляді), що може бути } \\
\text { витрачена }\end{array}$ & $\begin{array}{l}\text { Вибір країн-партнерів для в"їзного } \\
\text { туризму. Чим більшою сумою } \\
\text { розпоряджатиметься іноземний } \\
\text { турист у країні перебування, тим } \\
\text { більше прибутку отримають місцеві } \\
\text { компанії }\end{array}$ \\
\hline & $\begin{array}{c}\text { Дохід, } \\
\text { скоригований } \\
\text { за ПКС }\end{array}$ & $\begin{array}{l}\text { Перелік продукції (також із } \\
\text { зазначенням кількості), яку } \\
\text { можна придбати у різних } \\
\text { регіонах на одну й ту саму } \\
\text { наявну суму коштів }\end{array}$ & $\begin{array}{l}\text { Стратегії виїзного туризму: розподіл } \\
\text { країн на «дорогі» та дешеві», } \\
\text { стратифікація споживачів-клієнтів } \\
\text { компанії відповідно до їх рівня доходу, } \\
\text { фрормування загальної концепції турів } \\
\text { за різними географрічними напрямами } \\
\text { (масові чи VIP). } \\
\text { Оцінка потенціалу внутрішнього ринку - } \\
\text { якому відпочинку надаватиме перевагу } \\
\text { місцеве населення, чи вистачає } \\
\text { коштів у середньостатистичної родини } \\
\text { на подорожі й розваги, чи майже } \\
\text { увесь дохід витрачається на поточне } \\
\text { споживання? } \\
\end{array}$ \\
\hline \multirow[b]{2}{*}{ III } & ВВП (ВРП) & $\begin{array}{l}\text { Використання потенціалу } \\
\text { території, розвиненість } \\
\text { місцевої інфрраструктури, } \\
\text { стан довкілля, сталість } \\
\text { національної економіки }\end{array}$ & $\begin{array}{l}\text { Пошук посередників та } \\
\text { постачальників додаткових і супутніх } \\
\text { туристичних послуг, організація } \\
\text { ділових турів }\end{array}$ \\
\hline & ВНП & $\begin{array}{l}\text { 3-поміж усіх показників } \\
\text { найскладніше інтерпретується, } \\
\text { обов'язково потрібно } \\
\text { дослідити його змістові } \\
\text { складові. Виділення } \\
\text { персональних надходжень, } \\
\text { неоподатковуваного прибутку } \\
\text { корпорацій чи податкових } \\
\text { виплат, внеску резидентів в } \\
\text { залежності від частки кожної з } \\
\text { груп свідчитимуть про панівну } \\
\text { позицію на глобальному } \\
\text { ринку чи навпаки, країну із } \\
\text { втраченими ресурсами та } \\
\text { несприятливим інвестиційним } \\
\text { кліматом }\end{array}$ & $\begin{array}{l}\text { Ймовірність пошуку споживачів } \\
\text { на «сірому» чи «тіньовому» ринку, } \\
\text { якщо у структурі ВНП переважають } \\
\text { індивідуальні трансфрерти, споживачі } \\
\text { прагнуть витрачати кошти на } \\
\text { відпочинок у регіоні, відмінному від } \\
\text { постійного місця проживання. } \\
\text { За значної частки надходжень від } \\
\text { корпорацій - широка географрічна } \\
\text { присутність національного капіталу } \\
\text { та робочої сили за кордоном, космо- } \\
\text { політичне світосприйнятя резидентів } \\
\text { країни, усталені довготривалі зв'язки із } \\
\text { країнами-партнерами ТНК, присутність } \\
\text { на місцевому ринку конкурентів (турис- } \\
\text { тичних компаній) із даних країн }\end{array}$ \\
\hline
\end{tabular}


новив 13750 доларів - за цим показником Україна посіла 99-те місце у рейтингу 3-поміж 192 досліджуваних країн.

Для перевірки припущення щодо подібності структури туристичних потоків у країнах $з$ подібним коесріцієнтом ПКС порівняємо дані 2019 р. (табл. 2). Чим вищим є коефріцієнт ПКС, тим нижчою $€$ вартість уніфріковано-го споживчого кошика у порівнянні з фактичним (номінальним) доходом. Іншими словами, при однакових еквівалентних доходах споживач може придбати більше товарів і послуг у країнах з вищим коефріцієнтом ПКС. Зазначимо, що у таблиці відсутній коефріцієнт, менший за одиницю - це означає, що усі країни досліджуваної групи мають нижчі за середньосвітовий еквівалентний дохід на душу населення.

Таким чином, було виявлено деякі спільні риси, що характеризують структуру туристичних потоків у вартісному вимірі у країнах 3 близьким коесріцієнтом ПКС, але у межах підгруп виділяються тенденції, нетипові для інших країн (у кластерному аналізі це явище називається міжгруповою диференціацією і свідчить, разом із іншими критеріями, про правильність розподілу об'єктів). Отже, розходження між фрактичним (номінальним) та коригованим достатком чинить достатній прямий чи опосередкований вплив на модель споживання туристичних послуг (точніше оцінити ступінь впливу та притаманні йому чинники на основі тільки наведених даних складно, потрібно досліджувати інші фрактори, що характеризують добробут населення та інфрраструктуру національного туристичного ринку).

Пари показників можуть комбінуватися між собою, так можна отримати параметри із унікальними характеристиками. Індекс розвитку людини (Human Development Index, HDI) використовує як еталон достойного рівня життя валовий національний дохід на душу населення за ПКС, нормалізований за логарисрмічною шкалою. Припустиму, що ВНД було обрано за принципом акумулювання надходжень у країні для потреб ії резидентів, байдуже з яких джерел був отриманий прибуток. А от якби досліджувався стан ринку праці та вірогідність безробіття, краще було б використати ВВП/ВНД, адже тепер визначальним $€$ стан локальної ділової інфрраструктури, розвиток місцевих підприємств, які забезпечують резидентам робочі місця.

Наступна група показників доходу населення, яка дозволяє проводити класифрікацію споживачів туристичних послуг та відповідно - розробляти цільові стратегії, - це індекси на кшталт коефріцієнту Джині, за допомогою яких виділяють відмінні, часто протилежні за своїми характеристиками групи населення, спочатку у межах кожної країни, а потім країни із схожими ознаками об'єднуються у групи, i вже до них застосовуються різні моделі ділових відносин. Вірогідно, що бізнес-моделі у країнах із значним розшаруванням соціальних верств будуть відрізнятися від способів співробітництва, прийнятих у державах із проголошеною рівністю, оскільки суспільством підтримуються зовсім інші цінності. Але між собою дані групи національних економік будуть подібними, незважаючи на ймовірні відмінності у структурі національного господарства та різним ресурсним забезпеченням. Розмір абсолютного доходу на душу населення може коливатися у значному діапазоні, однак модель споживчої поведінки, вимоги до якості обслуговування та психологічне сприйняття зовнішнього оточення сильно не відрізнятимуться. Цей напрям досліджень $є$ надзвичайно цікавим, висловлені тези вимагають ґрунтовного підтвердження, що окреслює сореру подальшого наукового опрацювання i оцінки спочатку у межах одного макрорегіонального угруповання (із дотриманням подібності менталітету та ділових звичаїв), а потім перевірки висунутих гіпотез на вибірці країн із відмінним культурно-соціальним середовищем.

Висновки. Не існує однозначних рекомендацій щодо доцільності використання того чи іншого різновиду показника доходу на душу населення, який оптимально вирішував би завдання попередньої оцінки потенціалу споживчого ринку та схильності резидентів країни витрачати кошти на туристичні та рекреаційні послуги. Тим не менш, підприємствам, що використовують у плануванні власної діяльності стратегію диференціації, можна рекомендувати спосіб зіставлення антагонічних за сутністю показників одного підвиду 3 метою деталізації етапів реалізації стратегії та уникнення зайвих розрахунків у разі, коли стандартні у добірці та найбільш відомі критерії не відповідають за своєю сутністю цільовій стратегії. На прикладі найбільш поширених показників питомого середньорічного доходу було показано, як використання додаткових коригуючих коефріцієнтів може спростити процес прийняття рішення щодо напрямів географрічної чи типової спеціалізації під час оцінки потенціалу розвитку різних категорій туристичних потоків. 
Таблиця 2

Вихідні дані до порівняльного аналізу країн із економічним розвитком нижчим за середній

\begin{tabular}{|c|c|c|c|c|c|}
\hline $\begin{array}{c}\text { Країна } \\
\text { (національна економіка) }\end{array}$ & 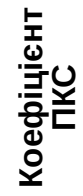 & 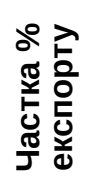 & 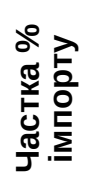 & 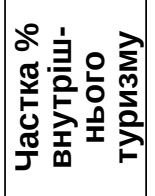 & Подібність структури турпотоків \\
\hline Єгипет $(21,4)$ & 4,39 & 52,1 & 11,5 & 36,4 & \multirow{4}{*}{$\begin{array}{l}\text { Відносно подібна, переважання } \\
\text { експорту та внутрішнього туризму, } \\
\text { в Україні переважає імпорт }\end{array}$} \\
\hline Україна $(13,1)$ & 4,08 & 15,3 & 49,6 & 35,1 & \\
\hline Узбекистан $(34,16)$ & 4,11 & 68,7 & 1,3 & 29,9 & \\
\hline Киргизстан $(48,31)$ & 4,09 & 45,1 & 30,8 & 24,1 & \\
\hline Пакистан $(38,27)$ & 3,41 & 5,5 & 18,9 & 75,5 & \multirow{12}{*}{$\begin{array}{l}\text { За виключенням Пакистану } \\
\text { і частково Індії та М'янми, } \\
\text { збалансована структура } \\
\text { (відносно рівномірний внесок } \\
\text { усіх трьох потоків) }\end{array}$} \\
\hline Індія $(27,18)$ & 3,27 & 15,3 & 12,3 & 72,4 & \\
\hline Непал $(49,40)$ & 3,30 & 35,1 & 22,4 & 42,5 & \\
\hline Туніс $(14,7)$ & 3,21 & 45,5 & 12,8 & 41,6 & \\
\hline М'янма $(44,30)$ & 3,71 & 56,1 & 2,7 & 41,2 & \\
\hline В'єтнам $(23,14)$ & 3,05 & 42,7 & 17,0 & 40,3 & \\
\hline Шрі Ланка $(1,3)$ & 3,29 & 51,3 & 21,7 & 26,9 & \\
\hline Лаос $(22,12)$ & 3,10 & 37,8 & 38,8 & 23,3 & \\
\hline Молдова $(4,2)$ & 3,38 & 41,5 & 35,7 & 22,8 & \\
\hline Монголія $(6,6)$ & 3,01 & 37,4 & 45,5 & 17,0 & \\
\hline Бутан $(19,8)$ & 3,56 & н/д & н/д & н/д & \\
\hline Мавританія $(37,25)$ & 3,22 & н/Д & $\mathrm{H} / \mathrm{g}$ & $\mathrm{H} / \mathrm{g}$ & \\
\hline Алжир $(3,5)$ & 2,90 & 2,4 & 7,5 & 90,1 & \multirow{25}{*}{$\begin{array}{l}\text { Переважання внутрішнього туризму } \\
\text { майже в половині країн підгрупи, } \\
\text { у цілому частка експорту (в'ізний } \\
\text { туризм) вища за внесок імпорту } \\
\text { (виїзний туризм). Спостерігається } \\
\text { полярна залежність обсягу } \\
\text { внутрішнього ринку та частки } \\
\text { експорту виділяються країни із } \\
\text { значним переважанням операцій на } \\
\text { внутрішньому ринку або високими } \\
\text { доходами від експорту та незначним } \\
\text { споживанням послуг резидентами }\end{array}$} \\
\hline Бангладеш $(31,28)$ & 2,68 & 3,6 & 12,0 & 84,4 & \\
\hline Котд'Івуар $(25,26)$ & 2,31 & 12,1 & 12,3 & 75,6 & \\
\hline Есватіні $(9,13)$ & 2,21 & 3,2 & 22,3 & 74,6 & \\
\hline Філіппіни $(5,9)$ & 2,65 & 12,7 & 13,9 & 73,3 & \\
\hline Сенегал $(41,42)$ & 2,37 & 23,1 & 14,2 & 62,6 & \\
\hline Кенія $(35,35)$ & 2,53 & 31,7 & 6,3 & 62,0 & \\
\hline Камерун $(39,38)$ & 2,49 & 19,3 & 21,3 & 59,5 & \\
\hline Гондурас $(24,22)$ & 2,31 & 25,8 & 17,2 & 57,0 & \\
\hline Ангола $(18,20)$ & 2,10 & 20,2 & 23,9 & 55,9 & \\
\hline Лесото $(46,45)$ & 2,42 & 3,2 & 46,4 & 50,5 & \\
\hline Гана $(26,22)$ & 2,48 & 24,3 & 28,7 & 47,0 & \\
\hline Бенін $(47,43)$ & 2,71 & 31,1 & 25,5 & 43,4 & \\
\hline Болівія $(11,10)$ & 2,52 & 33,3 & 26,4 & 40,2 & \\
\hline Нікарагуа $(32,24)$ & 2,87 & 39,5 & 20,4 & 40,1 & \\
\hline Нігерія $(29,29)$ & 2,55 & 9,4 & 52,0 & 38,5 & \\
\hline Замбія $(41,41)$ & 2,47 & 48,3 & 16,0 & 35,8 & \\
\hline Сальвадор $(2,11)$ & 2,18 & 51,2 & 16,9 & 32,0 & \\
\hline Марокко $(16,15)$ & 2,41 & 57,5 & 15,4 & 27,1 & \\
\hline Танзанія $(50,49)$ & 2,50 & 56,6 & 16,6 & 26,9 & \\
\hline Камбоджа $(40,36)$ & 2,82 & 69,1 & 10,8 & 20,1 & \\
\hline Коморські острови $(43,46)$ & 2,27 & 53,3 & 26,7 & 20,0 & \\
\hline КабоВерде $(8,17)$ & 2,01 & 78,8 & 11,3 & 9,9 & \\
\hline СанТоме і Принсіпі $(30,37)$ & 2,09 & 58,3 & 33,3 & 8,3 & \\
\hline Східний Тимор $(33,32)$ & 2,50 & н/д & н/Д & н/д & \\
\hline ПапуаНова Гвінея $(20,34)$ & 1,61 & 2,1 & 14,5 & 83,4 & \multirow{9}{*}{$\begin{array}{l}\text { Немає однорідності, переважання } \\
\text { внутрішнього туризму та імпорту } \\
\text { або експорту із рівними розподілом } \\
\text { доходів від внутрішнього } \\
\text { споживання та імпорту }\end{array}$} \\
\hline Зімбабве $(44,48)$ & 1,96 & 14,6 & 25,3 & 60,1 & \\
\hline Кірібаті $(15,33)$ & 1,39 & 16,7 & 33,3 & 50,0 & \\
\hline Соломонові острови $(28,50)$ & 1,15 & 60,0 & 20,0 & 20,0 & \\
\hline Вануату $(17,44)$ & 1,04 & 88,7 & 5,6 & 5,6 & \\
\hline Західний берег і сектор Газа $(7,19)$ & 1,82 & н/Д & $\mathrm{H} / \mathrm{A}$ & н/д & \\
\hline Конго, Респ. $(35,47)$ & 1,75 & н/д & н/д & н/д & \\
\hline Джибуті $(10,21)$ & 1,69 & н/д & н/д & н/д & \\
\hline Мікронезія $(12,39)$ & 1,07 & н/Д & н/Д & н/Д & \\
\hline
\end{tabular}

Вихідні дані для розрахунки частки турпотоку - у вартісному вимірі (доходи та витрати).

У дужках поруч із назвою країни перше число означає ранг у межах підгрупи за звичайим показником ВНП на душу населення, друге число - ранг за ВНП ПКС. 


\section{СПИСОК ВИКОРИСТАНИХ ДЖЕРЕЛ:}

1. Krajisnik, M. (2014) Causes and effects of the global decrease in demand. UTMS Journal of Economics, 5(2), 169-178.

2. Gül, H. (2017) Determining turkish households' tourism consumption expenditures in economic crisis. Advances in Hospitality and Tourism Research (AHTR), 7(1), 24-37. https://doi.org/10.30519/ahtr.456904

3. Canh, N.P., Su, D.T., \& Nguyen, B. (2020) Economic Uncertainty and Tourism Consumption. Tourism Economics, XX(X), 1-22. https://doi.org/10.1177/1354816620981519

4. Феленчак Ю.Б. Вплив рівня доходів населення на формування соціальної доктрини туризму. Проблеми системного підходу в економіці. 2019. № 4(2). С. 149-153. https://doi.org/10.32782/2520-2200/2019-4-52

5. Стамат В.М., Смирнова А.А., Савченко Н.С. Споживча поведінка на ринку туристичних послуг регіону. Вісник аграрної науки Причорномор'я. 2018. № 4. С. 23-34. https://doi.org/10.31521/2313-092X/2018-4(100)

6. Mora-Rivera, J., Cerón-Monroy, H., \& García-Mora, F. (2019) The impact of remittances on domestic tourism in Mexico. Annals of Tourism Research, 76, 36-52. https://doi.org/10.1016/j.annals.2019.03.002

7. Sanchez-Rivero, M., \& Pulido-Fernández, J.I. (2020) Global Estimation of the Elasticity of «International Tourist Arrivals/Income from Tourism». Sustainability, 12(20), 8707. https://doi.org/10.3390/su12208707

8. World Bank Open Data. URL: https://data.worldbank.org

9. World Travel \& Tourism Council. URL: https://wttc.org

\section{REFERENCES:}

1. Krajisnik, M. (2014) Causes and effects of the global decrease in demand. UTMS Journal of Economics, 5(2), 169-178.

2. Gül, H. (2017) Determining turkish households' tourism consumption expenditures in economic crisis. Advances in Hospitality and Tourism Research (AHTR), 7(1), 24-37. https://doi.org/10.30519/ahtr.456904

3. Canh, N.P., Su, D.T., \& Nguyen, B. (2020) Economic Uncertainty and Tourism Consumption. Tourism Economics, XX(X), 1-22. https://doi.org/10.1177/1354816620981519

4. Felenchak, Y. (2019) Vplyv rivnia dokhodiv naselennia na formuvannia sotsialnoi doktryny turyzmu [The impact of the population income level on the formation of social tourism doctrine]. Problemy systemnoho pidkhodu v ekonomitsi, 4(2), 149-153. https://doi.org/10.32782/2520-2200/2019-4-52 (in Ukrainian)

5. Stamat, V.M., Smyrnova, A.A., \& Savchenko, N.S. (2018) Spozhyvcha povedinka na rynku turystychnykh posluh rehionu [Consumer behavior at the market of tourist services of the region]. Visnyk ahrarnoi nauky Prychornomoria, 4, 23-34. https://doi.org/10.31521/2313-092X/2018-4(100) (in Ukrainian)

6. Mora-Rivera, J., Cerón-Monroy, H., \& García-Mora, F. (2019) The impact of remittances on domestic tourism in Mexico. Annals of Tourism Research, 76, 36-52. https://doi.org/10.1016/j.annals.2019.03.002

7. Sanchez-Rivero, M., \& Pulido-Fernández, J.I. (2020) Global Estimation of the Elasticity of «International Tourist Arrivals/Income from Tourism». Sustainability, 12(20), 8707. https://doi.org/10.3390/su12208707

8. World Bank Open Data. Retrieved from: https://data.worldbank.org

9. World Travel \& Tourism Council. Retrieved from: https://wttc.org 